\title{
A Systematic Literature Review on Ambush Marketing in Sport
}

Authors' contribution:

A) conception and design of the study

B) acquisition of data

C) analysis and interpretation of data

D) manuscript preparation

E) obtaining funding

\author{
Monika Piątkowska $^{1 \text { A,C-E }}$, Jolanta Żyśko ${ }^{2 \text { A,E }}$, \\ Sylwia Gocłowska ${ }^{1 \text { A,C,D }}$ \\ ${ }^{1}$ Josef Pilsudski University of Physical Education in Warsaw, Poland \\ ${ }^{2}$ Warsaw School of Tourism and Hospitality Management, Poland
}

\section{ABSTRACT}

The aim of the paper was to outline and evaluate the existing scientific achievements regarding the phenomenon of ambush marketing in sport, mark the dominating problematic areas, and create a literature database for the purposes of further research. The systematic literature review was conducted in the following stages: planning and conducting the review, analysis, and description of the results. The preliminary analysis included a combined number of 21,176 studies published between 1984-2013 in journals, books, and other sources included in analyzed databases, chosen using a meta-keyword: ambush. Analysis of the subject literature on the phenomenon of ambush marketing in sport allows for the classification of the works into three dominating research areas: identification of ambush marketing phenomenon, identification of the influence of ambush marketing practices on consumers, and identification of counter-ambush strategies. This review indicates the need for secondary research in social sciences in a more systematic way and more rigorously than it was done until now.

KEYWORDS

\section{Introduction}

Subject literature analysis is becoming a key element of the research process. The growing number of scientific journals and the articles within, combined with the growing pace of science development, makes proper analysis of modern scientific achievements and literature a key part of the research process and, very often, a scientific aim in itself.

"The pace of knowledge production in this field has been accelerating ever since [the post-WorldWar-II era] and has resulted in a body of knowledge that is increasingly fragmented and transdisciplinary as well as being interdependent from advancements in the social sciences" (Tranfield, Denyer, \& Smart, 2003, pp. 207-208).

Such a way of things forces a subject literature review to use, also in social sciences, more objective and repeatable methods of analysis, that enable the user to "manage diversity of knowledge for a specific 
academic inquiry" (Tranfield et al., 2003, p. 208). This is why social sciences more and more often reach out for methods that have been commonly used in sciences more positivistic in nature, e.g. medical sciences, and ones that rely on analyses of evidence. There are some methods of literature analysis that can be included in this group, e.g. meta-analysis or a systematic review.

For the purpose of this article a systematic review of the literature, which has mainly been used in the natural sciences, specifically in medical sciences, was chosen. Tranfield, Denyer, and Smart (2003) changed its range and successfully adapted it for a review of the literature on organization and management. This is how it became a basis for gathering solid knowledge, and also enabled the enrichment of the decisionmaking theory and practice, thus entering the area of practical management.

Today, a systematic literature review is a good alternative in many areas for a traditional, that is, narrative, literature review. The systematic literature analysis process creates a fairly complete and orderly knowledge database, which can be useful both for the theory and practice of management. This way it can be used for the purposes of marketing analyses and marketing itself. Tranfield, Denyer, and Smart (2003) also underline its "systematic, transparent, and reproducible manner". Impellizzeri and Bizzini (2012) pointed out the differences between the systematic and narrative subject literature review regarding some of the aspects mentioned in Table 1.

Table 1. Differences between a systematic and narrative subject literature review

\begin{tabular}{lll}
\hline Specification & Systematic & Narrative \\
\hline Research questions & Precisely formulated & Wide, non-specific \\
Methodology & Clearly defined & Not-defined or not defined enough \\
Research strategy & Clearly defined & Not-defined \\
Choice of research to analyze & Clearly defined & Not-defined \\
Ranking of research & Evidence-based & Underdeveloped \\
Research analysis & Clearly defined & Non-defined \\
Results interpretation & Objective & Subjective \\
\hline
\end{tabular}

Source: (Impellizzeri \& Bizzini, 2012).

The nature of a systematic literature review is remarkably positivistic, and results from clearly defined procedures which try to objectify the process through a series of operations that minimize biases and errors in seeking high quality evidence and examples of the studied phenomena in the subject literature (Weed, 2005). The aim of a systematic literature review is usually:

a) To outline and evaluate the existing scientific achievements of the studied phenomenon;

b) To outline the problematic areas and formulate research questions, the answers to which could enrich the existing knowledge base;

c) To evaluate the research methods used by other authors;

d) To evaluate the research results of other authors;

e) To create one's own literature base.

A systematic literature review is done using very clearly defined, reproducible procedures, which consist of several stages presented in Figure 1, and described in detail in the chapter regarding the methodological assumptions of this study. 


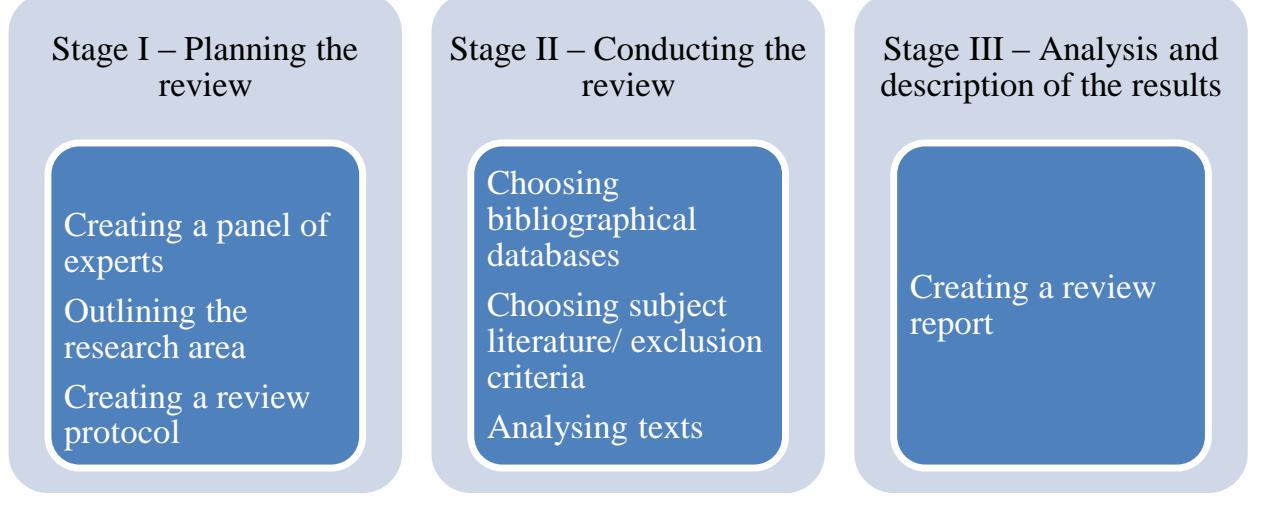

Figure 1. Systematic literature review stages

Source: own study based on (Tranfield et al., 2003).

\section{Methodological assumptions of this study}

In this study the systematic literature review method has been used in research regarding ambush marketing in sport, not only trying to describe the whole process, but also to do it in the most systematic, transparent, and reproducible way. The aim of the work was to outline and evaluate the existing scientific achievements regarding the phenomenon of ambush marketing in sport, mark the dominating problematic areas, and create a literature database for the purposes of further research.

For the purposes of this study, the systematic literature review was conducted in stages shown in Figure 1. All the stages and steps have been described in detail below.

\section{Stage I. Planning the review}

Step 1: Creating a panel - a team of experts to conduct the review

In order to start a systematic review of literature regarding theoretical and practical aspects of ambush marketing in sport, a panel of experts ("review panel") was created. The panel consisted of specialists in the theoretical and practical approaches to research on marketing in sport. The experts were chosen due to their knowledge and experience in the studied research area - namely they published at least ten papers on sport marketing and at least two papers on ambush marketing phenomenon in journals covered by international indexed databases. As for the experience and knowledge in creating literature reviews, a person with a degree in bibliometrics and dealing with bibliometric analyses concerning social sciences was selected. The review panel was directly involved in the process of literature review by regular meetings, discussion panels, and solving factual and practical problems connected with the research.

Step 2: Outlining the research area

The preliminary stage of the systematic literature review was in its nature a very interactive process, and consisted of defining, explaining, and perfecting research aims, as well as outlining the research area and the size of the necessary subject literature. Because of the complex, interdisciplinary area of research, this stage of the review was the key stage for the results of further research and for creating a transdisciplinary perception and understanding of the analyzed phenomenon of ambush marketing in sport.

\section{Step 3: Creating a review protocol}

Throughout the process of literature review, a review protocol was prepared in order to achieve maximum creativity in the process of the review. It will also enable the repetition of the research in the future. 


\section{Stage II. Conducting the review}

Step 1: Choosing bibliographical databases and creating key words in order to conduct the research

All the bibliographical databases available in the library of the University of Warsaw were reviewed (107 databases). Later several databases were chosen in terms of the discussed issues, which were similar to the widely understood social sciences. Finally, a decision was made to conduct the review based on 4 foreign bibliographical databases (EBSCO ${ }^{1}$, ISI Web of Knowledge, Science Direct, Scopus). The main reason for such a choice was the content of publications, which was the closest to the research topics discussed in this work.

A database search was conducted using keywords. The preliminary analysis included a combined number of 21,176 studies published in journals, books, and other sources included in analyzed databases, chosen using a meta-keyword: ambush. Then, in order to narrow the research area, other keywords were introduced: market* and sport, which resulted in 746 matches (Table 2).

Table 2. Preliminary results of the search of 4 bibliographical databases based on basic keywords

\begin{tabular}{|c|c|c|c|c|c|}
\hline & Science Direct & Ebsco & Scopus & $\begin{array}{l}\text { ISI Web of } \\
\text { Knowledge }\end{array}$ & Total \\
\hline Ambush (all fields) & 2453 & 14884 & 2898 & 941 (topic) & 21176 \\
\hline Journals/ books/ others & $1889 / 464 / 100$ & $\begin{array}{l}928 / 22 / 13 \\
934\end{array}$ & $2679 / 30 / 189$ & $\mathrm{~N} / \mathrm{D}$ & \\
\hline Ambush + market* & 195 & 790 & 238 & 32 & 1255 \\
\hline Journals/ books/ others & $113 / 74 / 8$ & $136 / 16 / 638$ & $230 / 2 / 6$ & N/D & \\
\hline Ambush + market $*+$ sport & 136 & 427 & 165 & 18 & 746 \\
\hline Journals/ books/ others & $61 / 76 / 12$ & $110 / 16 / 301$ & $162 / 1 / 2$ & N/D & \\
\hline
\end{tabular}

N/D - no data resulting from no such category in the bibliographical database.

Source: own study.

Step 2. Evaluating and choosing subject literature appropriate for the conducted research

In order to focus the literature search on the selected topics, additional keywords were selected, which can be found in Table 3. Furthermore, qualification criteria for the most appropriate bibliographical positions were chosen for further quality analysis:

a) Work published as a scientific article (original article or review);

b) Published in or after $1984^{2}$;

c) Publication longer than 5 pages;

d) Connection with the outlined research area;

e) Publication of the full-text article.

\footnotetext{
${ }^{1}$ The EBSCO databases included: Academic Search Complete, Agricola, British Library Document Supply Centre Inside Serials \& Conference Proceeding, Business Source Complete, Health Source - Consumer Edition, Health Source: Nursing/Academic Edition, LISTA, MEDLINE, MLA International Bibliography, MLA Directory of Periodicals, MasterFILE Premier, Political Science Complete, PsycArticles, PsycCritiques, Regional Business News, SPORTDiscus with Full Text.

${ }^{2}$ The first conscious use of ambush marketing took place during the $23^{\text {rd }}$ Summer Olympics in Los Angeles in 1984 , which can be considered the birth of the ambush marketing phenomenon (Shani \& Sandler, 1998b).
} 
Table 3. Results of the search of 4 bibliographical databases in context of additional keywords and established criteria

\begin{tabular}{|c|c|c|c|c|c|}
\hline & $\begin{array}{l}\text { Science } \\
\text { Direct }\end{array}$ & Ebsco & Scopus & $\begin{array}{l}\text { ISI Web Of } \\
\text { Knowledge }\end{array}$ & Total* \\
\hline+ Law & 32 & 24 & 41 & 1 & 67 \\
\hline + Sponsor* & 30 & 66 & 146 & 17 & 202 \\
\hline + Ethics & 17 & 3 & 26 & 1 & 35 \\
\hline + Strateg* & 43 & 31 & 126 & 10 & 154 \\
\hline + Consumer & 34 & 36 & 120 & 8 & 153 \\
\hline+ Methodolog* & 24 & 3 & 39 & 1 & 50 \\
\hline + Football & 22 & 14 & 46 & 2 & 66 \\
\hline + Event & 42 & 50 & 129 & 15 & 174 \\
\hline + Euro & 5 & 1 & 16 & 0 & 19 \\
\hline + Fifa & 7 & 4 & 19 & 3 & 24 \\
\hline + Olympics & 15 & 34 & 48 & 2 & 85 \\
\hline + Games & 32 & 32 & 98 & 3 & 132 \\
\hline Total & 303 & 298 & 854 & 63 & $1161 * *$ \\
\hline
\end{tabular}

* Number of articles after excluding articles appearing in several databases and not meeting the basic research criteria.

** Some articles were classified in several keyword categories, which is why the total number is higher than the total of the articles in Table 2 under the category ambush + market* + sport.

Source: own study.

As a result of the search of foreign bibliographical databases, 1161 articles published between 1984 and 2013 were subjected to an in-depth analysis. The process of final text choice was conducted in several phases. The title of the work underwent a preliminary analysis (when in doubt, the whole text was analyzed), and on this basis the text was included in or excluded from a later quality analysis of its contents.

\section{Stage III. Analysis and description of the results}

Reports on the results of the systematic literature review were made in a descriptive and factual order. Each analysis was made using the EndNote X7 computer program, which allows the user to create their own bibliographical databases. The quality analysis of the texts was made using NVivo 10 software.

\section{Study results}

Analysis of the subject literature on the phenomenon of ambush marketing in sport allows for the classification of the works into three dominating research areas (Figure 2).

The vast majority of articles that try to identify the phenomenon of ambush marketing refer to the area of sport and different aspects of sponsorship in sport. This is a result of the fact that ambush marketing was first discovered during the Summer Olympics in Los Angeles in 1984 (Burton \& Chadwick, 2009). An attempt to identify this phenomenon was made 4 years later by Bayless, who explained ambush marketing in a way that is in use to this day. Pitt et al. (2010, p. 2) describe this phenomenon as a "purposeful and false association by a company not sponsoring an event toward the end of deriving benefits similar to those afforded official sponsors".

Three case studies dominate this area - all of them identify the case, analyze the position of the ambusher and the sponsor during a given sport event. The aim of these publications is, apart from depicting these incidents, to present conclusions necessary to prevent the phenomenon of ambush marketing. 


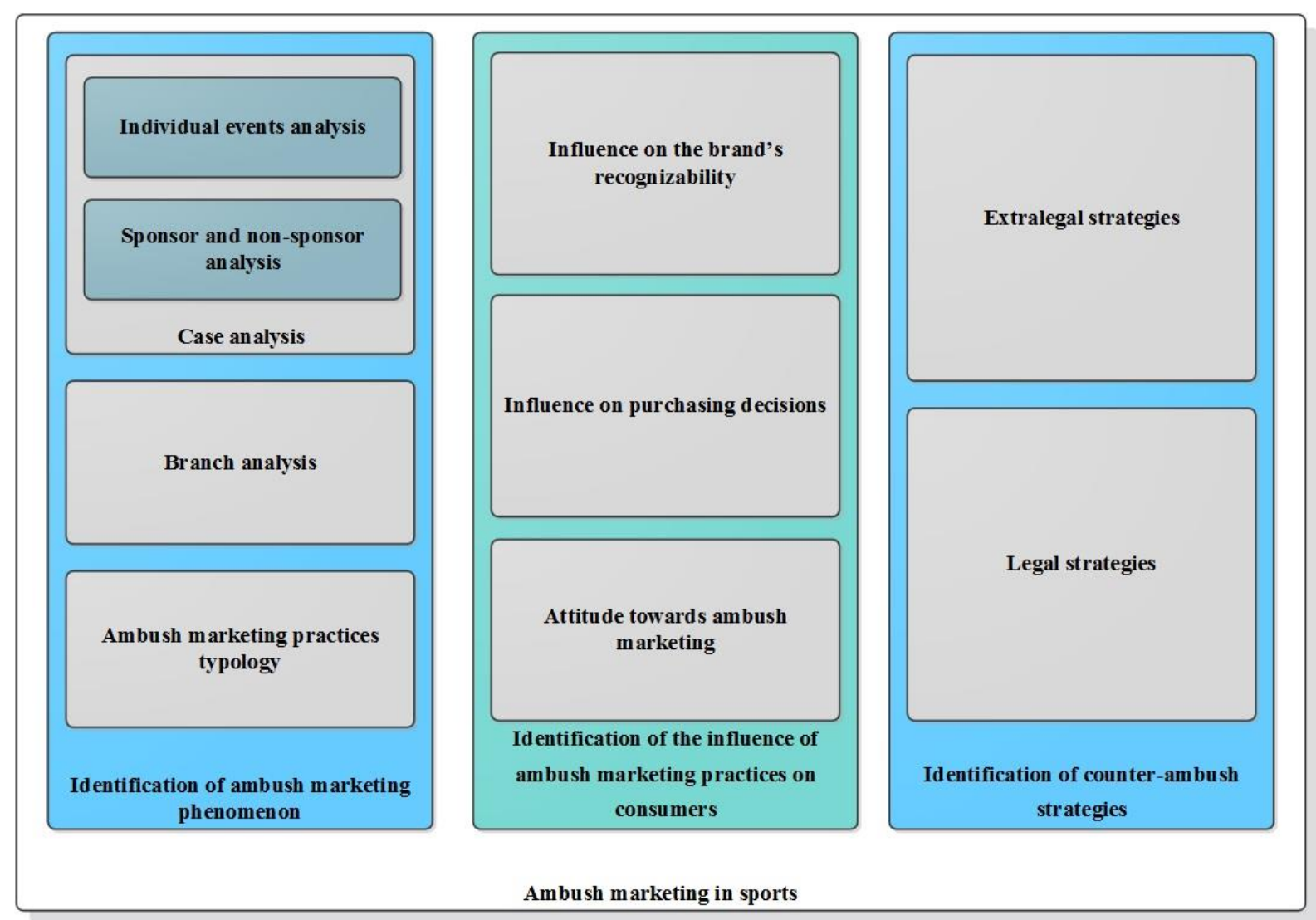

Figure 2. Research areas found during the systematic literature review on ambush marketing in sports Source: own study.

Most authors decided to work on cases of ambush marketing during the Olympics. Pacut (2012) described the case of the Budweiser Budvar Brewery company, which tried to create a connection between the company and the 2006 Olympics through advertisements. As a result of these actions, the Czech Court of Justice found the company guilty of violating the Olympic rights and imposed a fine and demanded an apology on behalf of the Czech Olympic Committee. This is one of the few examples of lawsuits against ambushers that ended in conviction. Hoek (1997) worked on a similar issue, describing the actions of the Telecom brand, which illegally used the five Olympic circles symbol in their campaign. Brown (2000) focused on cases of ambush actions undertaken by MasterCard towards Visa, and Quantas Airlines towards Ansett Airlines. These brands are in direct competition with each other, which is why problems of the receivers recognizing the official sponsors, due to intense and aggressive advertising campaigns of the aforementioned ambushers, were common throughout several consecutive Olympics. The main aim of the publication by Pitt et al. (2010) was to analyze a controversial case of ambush marketing which took place in Beijing during the 2008 Olympics. During this event Li Ning, a popular Chinese athlete and owner of the sportswear brand with the same name, was suspected of ambush marketing towards the Adidas brand, an official sponsor of the Olympics. This case was widely discussed by the media and was dubbed the Li Ning Effect. The authors of the publication came up with several important conclusions for the sponsors, and should be treated as a lesson coming from Li Ning's case.

Apart from the Olympics, ambush marketing can be found in other big media mega-events. In the United States many cases of such practices can be found at American Football games. Even the sponsors of the NFL (American National Football League), the biggest football league in the country, are not free from ambushers trying to play the role of official sponsors of the event. Fortunato and Melzer (2008) tackled the problem of allowing the sponsorship rights of one event to be sold to companies working in the same branch and being in direct competition with each other. The same problem, also regarding the NFL, was described by McKelvey (2006), who analyzed the situation of Coca-Cola and Pepsi. Both brands, which are direct 
competitors in the market of non-alcoholic beverages, had been fighting for the rights of being connected to the games for many years, either by being sponsors of the entire league, or individual teams. Cobbs (2011), on the other hand, described cases of MasterCard and AT\&T filing lawsuits against FIFA and NASCAR, respectively, for non-performance of the agreement regarding the protection of their sponsorship rights.

Subject literature also includes work that shows the use of ambush marketing in the context of the entire branch. Sponsorship of one discipline (cricket) by several companies from one product category of the alcoholic beverages brand, taking into consideration different forms of sponsorship, has been described by Jones (2010).

Other work can also be distinguished in this field, work by authors, who identified cases of ambush marketing during many sports events and on this basis tried to undergo a typology of this practice. The earliest classification of ambush marketing practices was formulated by Meenagham in 1994. The ambush marketing strategies created and classified by this author are considered the original ones and served for a long time as the basis for research on the studied phenomenon.

The first attempts at ambush marketing in sport were most commonly made through ways of associative marketing, also called direct ambush marketing. The specific fight between the organizers and companies that wanted to make use of sports events organization gave birth to new, more sophisticated and elaborate ambush marketing methods and new, more creative marketing strategies of companies competing for benefits coming from associating them with a given event, which took the form of invasive marketing. Due to a number of ambush marketing classifications, the main trends can be found in Table 4 .

Another highlighted research area refers to analysis of the influence of ambush marketing on the consumer. Most of the work raises the issue of sponsor recognizability, the awareness of its brand, and the effectiveness of sponsorship as opposed to ambush marketing. The authors, who present the results of their studies on consumers regarding the recognizability of sponsors and non-sponsors of a given sport event (Bettina Cornwell, Maignan, \& Irwin, 1997; Grohs, Wagner, \& Vsetecka, 2004; Hoek, 1997; Johar, Pham, \& Wakefield, 2006; McDaniel \& Kinney, 1998; McKelvey, Sandler, \& Snyder, 2012; Meenaghan, 1998a; Nufer, 2009; Nufer \& Bühler, 2010; Pitt et al., 2010; Sandler \& Shani, 1989), point out that the consumers have always had trouble identifying industries which were official sponsors of a given event, and distinguishing between them and sponsors that use ambush marketing. The research results coming from different countries almost unanimously indicate that ambush marketing campaigns are incredibly efficient. Some results indicate, however, that this effectiveness, and thus weaker sponsor recognition, is affected by several key factors. These factors are most of all the connection between the sponsor and the sport event and the interest level, as well as the engagement of the receiver in the given sport event (Grohs et al., 2004; Portlock \& Rose, 2009). The position of the sponsor and the ambusher in the media is also important. A vast majority of the published works concentrates on big sports events, such as the Olympics or world championship in different sport disciplines. Furthermore, some researchers have tried to evaluate the influence of communication through sponsorship on the consumers' purchasing decisions. Kinney and McDaniel (1996) compared the consumers' purchasing reaction in response to advertisements of official sponsors and ambushers. They concluded that there is no noticeable difference between the purchasing decision in response to advertisements by the sponsor or the ambusher. Séguin et al. (2005), in turn, proved that the influence of ambush marketing practices on purchasing decisions differs depending on the country of origin of the respondents. While the host of the 2000 Olympics was Australia, they had studied the consumers from Canada, USA, and France. The results showed that the citizens of France had the lowest purchasing intention to buy products of the sponsors of the Olympics (16\%) compared to non-sponsors. By comparison, $31 \%$ of the respondents from Canada would have bought products of the sponsors, and $48 \%$ of the respondents would not have bought products of the ambusher. O'Reilly et al. (2008) described the actions of the ambushers as lowering the purchasing intentions regarding official sponsors. Macintosh et al. (2012), on the other hand, pointed out that the purchasing intention is also influenced by the interest level in the sport event. This was also the area of interest of McDaniel and Kinney (1998), who described the correlation of the purchasing intention in response to sponsorship in relation with the sex of a respondent. 
The authors did not notice any significant behavioral differences between men and women in response to advertisements by the sponsors and the ambushers.

Another research aspect in the area of consumer research refers to the perception of ambush marketing and the attitude of the respondents towards such practices (Lyberger \& McCarthy, 2001; McKelvey et al., 2012; Meenaghan, 1998a; O'Reilly et al., 2008; Portlock \& Rose, 2009; Séguin et al., 2005; Shani \& Sandler, 1998a). The authors emphasize that consumers do not know the nature and meaning of the discussed phenomenon and are not aware which brands are official sponsors of the event, and which are only disguised as partners. Furthermore, most of the respondents have a negative opinion on ambush marketing, condemning such practices and deeming them unethical.

The purpose for starting research of this topic was often not only evaluation of the effectiveness of industries' sponsorship actions, but also a discussion on the effectiveness of the Olympics, and other big sports events, organizers' efforts towards minimizing the actions of ambush marketers (Robinson \& Bauman, 2008; Shani \& Sandler, 1998a). The authors also try to identify the ambush marketing practices, and in the long run find means of counteracting them and prevent them from happening (Kelly, Cornwell, Coote, \& McAlister, 2012; Pitt et al., 2010; Séguin et al., 2005; Taylor, 2012).

Ambush marketing is also considered a great threat to the recognizability of the sponsors and the effectiveness of their advertising campaigns (Meenaghan, 1998b; O'Reilly et al., 2008; Pham \& Johar, 2001). O'Reilly and Horning (2013) pointed out, that ambush marketing is an important element to be considered during the process of decision making for sponsoring a sport event and planning a communication strategy with respondents. Ambush marketing is treated similarly, but regarding the Olympics, by Giannoulakis et al. (2008). The authors think that actions of the ambushers are at present, and will be in the future, one of the key challenges for the organizers of the Olympics, who require effective counteracting strategies against this phenomenon.

Another field which appears in the consumer research regarding ambush marketing is the perception of such practices from the point of view of the sponsor company (Farrelly, Quester, \& Greyser, 2005). Based on a research survey conducted on managers of sponsor companies, the authors identified behavioral trends of the ambushers. As it turns out, through time companies using ambush marketing become consistently more creative in their attempts to connect their brand to a sport event. Furthermore, large ambush corporations employ the best attorneys in order for their campaigns to use loopholes in the legal system. Some companies simply exploit sport and their association to it for years in their advertising campaigns, building their image of companies that support sports events or individual athletes. This way they build a long-term strategy of marketing communication based on ambush marketing. The authors underlined the need for close and long-term cooperation between sponsors and organizers of sports events in order to effectively block ambush marketing tactics, as such actions are incredibly harmful for both sides - the sponsor and the organizer. From the sponsor's point of view they decrease the effectiveness of sponsorship, and from the point of view of the sport event organizer, ambush marketing lowers the value of sponsorship contracts and deters potential partners.

The articles in this category are connected in the way of perceiving ambush marketing and defining it as, on the one hand, a side effect of sports sponsorship, and on the other, as a purposeful action parallel to sponsorship. As studies show, companies using ambush marketing practices are efficient rivals for the title of official sponsors of a sport event in the mind of the consumer. 
Table 4. Ambush Marketing Typologies Available in the Subject Literature

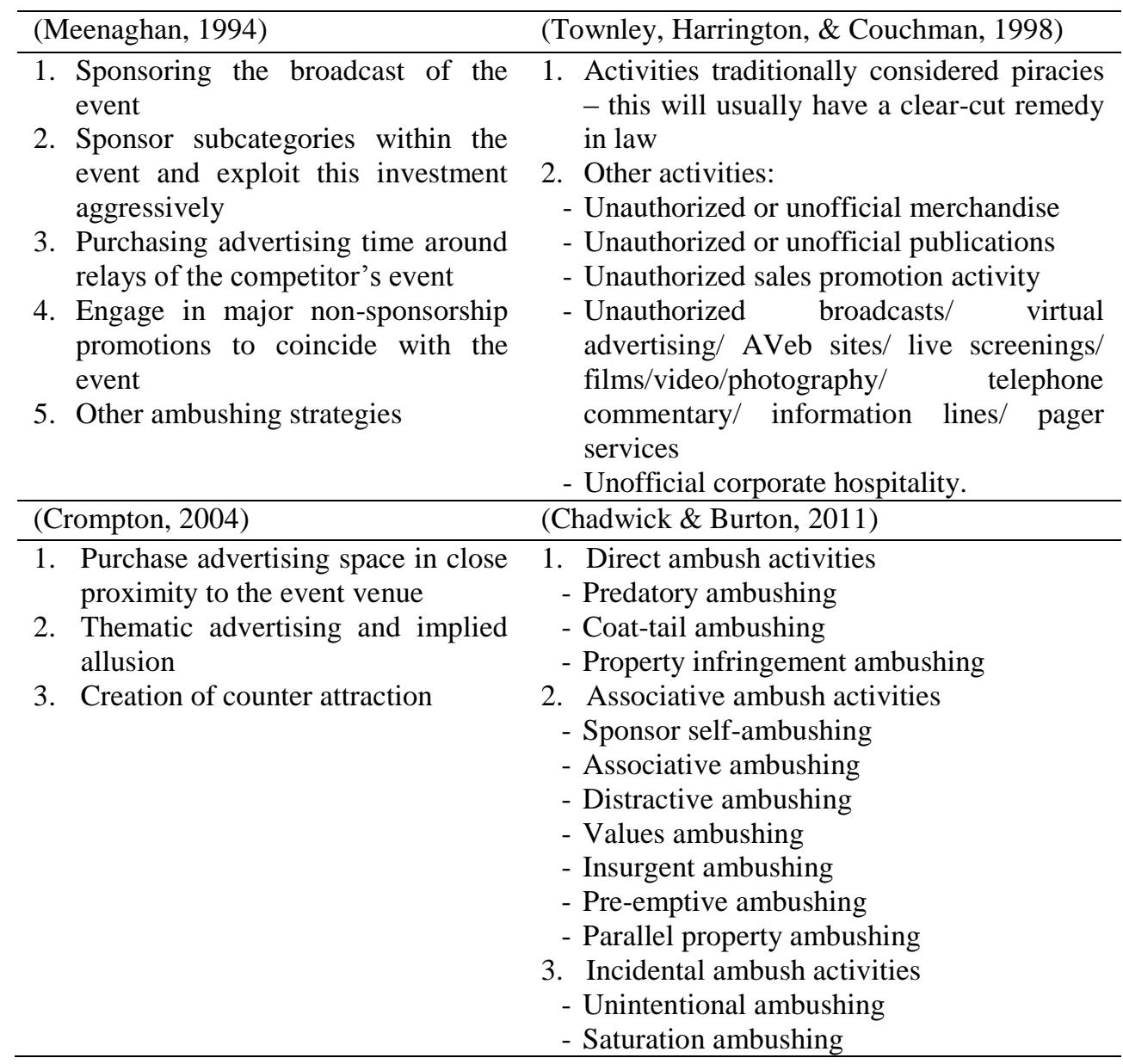

Source: own study.

Another research area that was revealed through analysis of the available subject literature points was the existence of different strategies of counteracting ambush marketing practices used during the organization of big sports events. As it is shown by the evolution of unfair marketing actions, the tools and location of advertisements have changed, as well as the means of exposition, into more creative ones, such as using the audience or athletes as promotional instruments. Due to the severity and serious consequences of the ambush marketing phenomenon scientists noticed the necessity for fighting the great strength of ambush marketing practices through devising efficient counteracting strategies. The subject literature describes two kinds of strategies: extralegal and legal means of fighting ambush marketing. The review of these strategies is shown in Table 5. 
Table 5. Review of strategies for counteracting the ambush marketing phenomenon

(Meenaghan, 1994)
1. Pressurize event owners to protect their events
2. Link event and broadcast sponsorship
3. Anticipate potential competitive promotions
4. Exploit the sponsorship rights secured
5. Resort to legal action

(Townley et al., 1998)

1. Control of the intellectual property. Protect event mascots and logos via trademark registrations

2. Control of the event environment. Control the venues and locality

3. Control of the event partners. Control the participants, sponsors, and the media

\begin{tabular}{|c|c|}
\hline (Crompton, 2004) & (Hartland \& Skinner, 2005) \\
\hline $\begin{array}{l}\text { 1. Specifying how tickets will be dispersed to avoid a } \\
\text { competitor accessing blocks of tickets and awarding them } \\
\text { as prizes }\end{array}$ & $\begin{array}{l}\text { 1. Using unique logos and brand names for } \\
\text { official sponsors } \\
\text { 2. Making clear exclusivity agreements }\end{array}$ \\
\hline $\begin{array}{l}\text { 2. Web links to the event site and from the event site to the } \\
\text { sponsor's site, and to co-sponsor sites }\end{array}$ & $\begin{array}{l}\text { 3. Forming a sponsor's protection } \\
\text { committee "directed by competent sports }\end{array}$ \\
\hline $\begin{array}{l}\text { 3. Technological detection which puts video insertions into } \\
\text { a television broadcast to create advertising messages } \\
\text { when none existed, and delete ones where they exist }\end{array}$ & $\begin{array}{l}\text { lawyers" } \\
\text { 4. Integration of official sponsor's activities } \\
\text { with examples such as providing }\end{array}$ \\
\hline $\begin{array}{l}\text { 4. Event owners prohibiting broadcast partners from "sub- } \\
\text { letting" the event's trademark rights to non-official } \\
\text { sponsors through the use of composite logos and titles } \\
\text { that convey an official association between the non- } \\
\text { sponsor and the event }\end{array}$ & $\begin{array}{l}\text { exchange media for sponsors, organizing } \\
\text { associated events for official sponsors, } \\
\text { and encouraging pooling between official } \\
\text { sponsors }\end{array}$ \\
\hline $\begin{array}{l}\text { 5. Having a host city and/or event site ban advertising that } \\
\text { directly competes with official sponsors }\end{array}$ & \\
\hline 6. Comprehensive use of the platform the event provides & \\
\hline (McKelvey \& Grady, 2008) & (Burton \& Chadwick, 2009) \\
\hline Sponsorship program protection strategies & 1. Reactive strategies, aimed at countering \\
\hline 1. Pre-event education and public relation initiatives & ambush attempts and compensating for \\
\hline Onsite policing & the damages caused \\
\hline 1. Ambush marketing patrols & "Name and shame" \\
\hline 2. Covering of non-sponsor logos & Legal action \\
\hline 3. Securing commercial inventory & 2. Proactive attempts, focused on \\
\hline $\begin{array}{l}\text { 4. Controlling access to ticket blocks and hospitality } \\
\text { opportunities }\end{array}$ & $\begin{array}{l}\text { anticipating, deterring and preventing } \\
\text { such campaigns }\end{array}$ \\
\hline 5. Establishment of "clean zones" & - Pressurize event owners to protect \\
\hline $\begin{array}{l}\text { 6. Contractual prohibitions in participant } \\
\text { agreements/spectator tickets }\end{array}$ & $\begin{array}{l}\text { - Link event and broadcast sponsorship } \\
\text { - Anticipate potential competitive }\end{array}$ \\
\hline 7. Ambush protection in the Bid City process & - Adopt anti-ambushing laws \\
\hline 8. Enactment of trademark protection legislation & \\
\hline
\end{tabular}

(Chase \& Kurnit, 2010)

1. The purchase of all advertising space and media time

2. Require event host locations to establish "clean zones"

3. Public relations activities

4. "Reminder" letters

5. Maintain strict control over event ticketing

6. Legal action

Source: own study.

The extralegal methods of fighting ambush marketing include strategies defensive in nature, which focus on pointing out the non-ethical, inappropriate, or illegal aspects of promotional campaigns of the ambusher in different media ${ }^{3}$. Part of this strategy focuses on foreseeing, intimidating, and preventing the practices of ambush marketing by, for example, putting pressure on the organizers of a given sport event in

\footnotetext{
${ }^{3}$ It must be considered, however, that this strategy often has a reverse effect - drawing the attention of the media to the inappropriate behavior of an enterprise may ensure more PR activity and bring much more promotional benefits.
} 
order to protect the rights of the sponsors, or offering sponsorship bundles of the event, transmission, and in some cases even time for commercials during the transmission. Many sports organizations have noticed the gravity of the threat of ambush marketing and have taken a firm position in protecting the value of their sports events and the interest of potential sponsors. Being aware of the potential damage of their product, the organizers of the world's biggest sports events (IOC, FIFA) have taken offensive actions against ambushers. Not only have the sponsorship agreements been refined, but also individual programs for rights protection have been implemented.

Many studies on the strategies of fighting ambush marketing describe legal actions taken to minimize the negative effects of the phenomenon. As it was proved by the research of Hartland and Skinner (2005, p. 245), extralegal actions taken by sponsors and organizers "to block ambush attempts are only enforceable with recourse to the law". Most of the authors focused on describing the legislative specifics of the host countries of the Olympics (Alexandrakis, 2009; Ellis, Gauthier, \& Séguin, 2011; Grady, McKelvey, \& Bernthal, 2010; Hartland \& Williams-Burnett, 2012; James \& Osborn, 2011; Stuart \& Scassa, 2011), or describing actions taken by the International Olympic Committee in order to protect the rights of the official sponsors of the event (Payne, 1998; Stuart \& Scassa, 2011). There is also work which presents normative acts on fighting ambush marketing in a given market, e.g. the Indian market (Mishra \& Mishra, 2011). All the aforementioned authors have commented in their articles on the practical implications of the introduced acts, underlining the need for finding new legal ways to block ambush marketing practices.

In the normative acts described by the authors, one can identify two approaches to the problem. Some of the host-countries decide to issue a special act that functions only for the period of a given event. Others ground their actions on the existing law on protection and enforcing the right for intellectual property (trademark protection, copyright protection, industrial property protection) or the fight with unfair competition.

In all three described research areas (Figure 2) the authors try to take a stand regarding the ethical aspects of using ambush marketing. Due to the implemented way of the distinction of research areas, a decision was made not to create a new area.

However, it must be stated that there is little work by authors who study ambush marketing in terms of the morality of such actions. The discussion on whether this kind of marketing is an immoral practice, or if it is simply an action based on creative and unconventional marketing communication,present in many circles. The answer to this question appears simple. Ambush marketing is considered an immoral action from the organizer's point of view, who observes gaining profit by industries which do not support a given event in any way. The organizers claim that as a result of such parasitic actions, the value of sponsorship will decrease, and the development of sport will later be in danger. Similar conclusions are drawn by official sponsors, who will not want to invest in sports events any longer. Despite many protests, there is a group of industries that keeps using ambush strategies, thinking that they are simply a part of an aggressive business activity, based on a strong economic background. As "justification" for their actions, they claim that the price of sports agreements are too high and therefore consider such actions as a justified form of competitive action, or even deny that what they do can be called ambush marketing.

Doust (1997) claims that every evaluation of the ethicality of such actions depends on the kind and context of a case. He agrees with the opinion that it is very difficult to unequivocally consider ambush marketing as an unethical action, for there is no detailed ethical code on conducting marketing actions. Meenaghan (1994) proposes a more rigorous industry evaluation criteria, which is in no way connected with a sport event, and is more indulgent with companies which are sponsors of a transmission of a sport event or national companies. Some researchers also stress that there are companies that use ambush marketing in order to gain a business advantage, achieve a required financial result, not to purposefully misguide the consumer (Crompton, 2004; Meenaghan, 1994, 1996). A somewhat different approach to the issue of ambush marketing ethics is presented by O'Sullivan and Murphy (1998, p. 358), who discuss the actions of ambush marketers in regards to 4 theories of ethics: "utilitarianism, duty-based ethics, stakeholder and virtue 
ethics". Referring to these theories, the authors consider the evaluation of ambush marketing in relation to the consequences provoked by such actions, and to the intentions of companies using ambush marketing.

Not many publications on this topic univocally point out the peculiarity of ambush marketing and the difficulty of indisputable evaluation of such actions. Researchers agree that the ethics of ambush marketing depends on many factors, e.g. the understanding and definition of the phenomenon itself, kind of action, or point of reference.

\section{Conclusions}

This review indicates the need for secondary research in social sciences in a more systematic way and more rigorously than it was done until now. Such systematic analysis of the literature on ambush marketing in sport allowed for the outlining, structuring, and evaluation of the current scientific achievements and available publications on this subject. The subject literature is dominated by works that describe ambush marketing based on the analysis of cases, branches, and individual sports events. Most of the work is descriptive in nature. Analysis of these cases allowed for the creation of typologies and strategies of ambush marketing in sport. The description and taxonomy of the ambush marketing strategies allowed for the description and taxonomy of methods and strategies of counteracting such practices. The efficiency of such actions was analyzed in a limited way, and studies conducted in this field indicate poor performance of taken actions. This analysis allows for finding fields for further study.

The subject literature lacks more holistic works on the influence of specific education and awareness actions implemented as intervention programs, the aim of which was to counteract the ambush marketing phenomenon in sport. It also lacks studies on analysis of the methodology of studying the phenomenon of ambush marketing in sport. Although a brief observation of the publications used in this study clearly indicates that the list consists mostly of survey research conducted on the basis of questionnaires, the subject literature was not the aim of the review.

\section{Acknowledgement}

This paper was prepared under the statutory framework DS. 138 "Preventing unfair practices ambush marketing in the organization of major sporting events", financed by the Ministry of Science and Higher Education in Poland.

\section{REFERENCES}

Alexandrakis, V. (2009). The fight against ambush marketing and London 2012 : How has this phenomenon dealt with by the UK legislation and what's the role of the EU legislation? International Sports Law Review Pandektis, 8(1/2), 156-165.

Bettina Cornwell, T., Maignan, I., \& Irwin, R. (1997). Long-term Recall of Sponsorship Sources: An Empirical Investigation of Stadium and Sport Cafe Audiences. Asia-Australia Marketing Journal, 5(1), 45-57. DOI: http://dx.doi.org/10.1016/S1320-1646(97)70257-0

Burton, N., \& Chadwick, S. (2009). Ambush marketing in sport: An analysis of sponsorship protection means and counter-ambush measures. Journal of Sponsorship, 2(4), 303-315.

Chadwick, S., \& Burton, N. (2011). The evolving sophistication of ambush marketing: A typology of strategies. Thunderbird International Business Review, 53(6), 709-719.

Chase, C.R., \& Kurnit, R. (2010). Fighting for what is left of exclusivity: Strategies to protect the exclusivity of sponsors in the sports industry. Journal of Sponsorship, 3(4), 379-393.

Crompton, J. (2004). Sponsorship ambushing in sport. Managing Leisure, 9(1), 1-12.

Doust, D. (1997). The ethics of ambush marketing. Cyber-Journal of Sport Marketing, 1(3).

Ellis, D., Gauthier, M.E., \& Séguin, B. (2011). Ambush marketing, the Olympic and Paralympic Marks Act and Canadian national sports organisations: Awareness, perceptions and impacts. Journal of Sponsorship, 4(3), $253-271$. 
Farrelly, F., Quester, P., \& Greyser, S.A. (2005). Defending the co-branding benefits of sponsorship B2B partnerships: The case of ambush marketing. Journal of Advertising Research, 45(3), 339-348.

Giannoulakis, C., Stotlar, D., \& Chatziefstathiou, D. (2008). Olympic sponsorship: Evolution, challenges and impact on the Olympic Movement. International Journal of Sports Marketing and Sponsorship, 9(4), 256-270.

Grady, J., McKelvey, S., \& Bernthal, M.J. (2010). From Beijing 2008 to London 2012: Examining event-specific Olympic legislation vis-à -vis the rights and interests of stakeholders. Journal of Sponsorship, 3(2), 144-156.

Grohs, R., Wagner, U., \& Vsetecka, S. (2004). Assessing the Effectiveness of Sport Sponsorships - An Empirical Examination. Schmalenbach Business Review (SBR), 56(2), 119-138.

Hartland, T., \& Skinner, H. (2005). What is being done to deter ambush marketing? Are these attempts working? International Journal of Sports Marketing \& Sponsorship, 6(4), 231-241.

Hartland, T., \& Williams-Burnett, N. (2012). Protecting the Olympic brand: Winners and losers. Journal of Strategic Marketing, 20(1), 69-82.

Hoek, J. (1997). 'Ring Ring': Visual Pun or Passing Off?: An Examination of Theoretical and Research Issues Arising from Ambush Marketing. Asia-Australia Marketing Journal, 5(1), 33-43. doi: http://dx.doi.org/10.1016/S13201646(97)70256-9

Impellizzeri, F.M., \& Bizzini, M. (2012). Systematic Review and Meta-Analysis: A Primer The International Journal of Sports Physical Therapy, 7(5), 493-503.

James, M., \& Osborn, G. (2011). London 2012 and the Impact of the UK's Olympic and Paralympic Legislation: Protecting Commerce or Preserving Culture? Modern Law Review, 74(3), 410-429.

Johar, G.V., Pham, M.T., \& Wakefield, K.L. (2006). How event sponsors are really identified: A (baseball) field analysis. Journal of Advertising Research, 46(2), 183-198.

Kelly, S.J., Cornwell, T.B., Coote, L.V., \& McAlister, A.R. (2012). Event-related advertising and the special case of sponsorship-linked advertising. International Journal of Advertising, 31(1), 15-37.

Kinney, L., \& McDaniel, S.R. (1996). Strategic implications of attitude-toward-the-ad in leveraging event sponsorships. Journal of Sport Management, 10(3), 250-261.

Lyberger, M.R., \& McCarthy, L. (2001). An assessment of consumer knowledge of, interest in, and perceptions of ambush marketing strategies. Sport Marketing Quarterly, 10(3), 130-137.

Macintosh, E., Nadeau, J., Séguin, B., O'Reilly, N. J., Bradish, C., \& Legg, D. (2012). The Role of Mega-Sports Event Interest in Sponsorship and Ambush Marketing Attitudes. Sport Marketing Quarterly, 21(1), 43-52.

McDaniel, S.R., \& Kinney, L. (1998). The implications of recency and gender effects in consumer response to ambush marketing. Psychology and Marketing, 15(4), 385-403.

McKelvey, S., \& Grady, J. (2008). Sponsorship program protection strategies for special sport events: Are event organizers outmaneuvering ambush marketers? Journal of Sport Management, 22(5), 550-586.

McKelvey, S., Sandler, D.M., \& Snyder, K. (2012). Sport Participant Attitudes Toward Ambush Marketing: An Exploratory Study of ING New York City Marathon Runners. Sport Marketing Quarterly, 21(1), 7-18.

Meenaghan, T. (1994). Point of view: ambush marketing: immoral or imaginative practice? Journal of Advertising Research, 34(5), 77-88.

Meenaghan, T. (1996). Ambush marketing - A threat to corporate sponsorship. Sloan Management Review, 38(1), 103113.

Meenaghan, T. (1998a). Ambush marketing: Corporate strategy and consumer reaction. Psychology and Marketing, 15(4), 305-322.

Meenaghan, T. (1998b). Guest Editorial Ambush Marketing: Examining the Perspectives, Psychology \& Marketing, pp. 301-304. Retrieved from

http://search.ebscohost.com/login.aspx?direct=true\&db=bth\&AN=11647021\&lang=pl\&site=ehost-live

Mishra, P., \& Mishra, S. (2011). The Legal Perspective of Ambush Marketing: an Arm Length Study in Indian Scenario. International Journal of Business Insights \& Transformation, 4(2), 128-135.

Nufer, G. (2009). Sponsoring the FIFA Football World Cup: The good, the bad and the surprising. Journal of Sponsorship, 2(3), 241-249.

Nufer, G., \& Bühler, A. (2010). How effective is the sponsorship of global sports events? A comparison of the FIFA World Cups in 2006 and 1998. International Journal of Sports Marketing and Sponsorship, 11(4), 303-319.

O'Reilly, N., Lyberger, M., McCarthy, L., Séguin, B., \& Nadeau, J. (2008). Mega-Special-Event Promotions and Intent to Purchase: A Longitudinal Analysis of the Super Bowl. Journal of Sport Management, 22(4), 392-409.

O'Reilly, N.J., \& Lafrance Horning, D. (2013). Leveraging sponsorship: The activation ratio. Sport Management Review, In press. doi: http://dx.doi.org/10.1016/j.smr.2013.01.001 
O'Sullivan, P., \& Murphy, P. (1998). Ambush marketing: The ethical issues. Psychology and Marketing, 15(4), 349366.

Payne, M. (1998). Ambush marketing: the undeserved advantage. Psychology \& Marketing, 15(4), 323-331.

Pham, M.T., \& Johar, G.V. (2001). Market prominence biases in sponsor identification: Processes and consequentiality. Psychology and Marketing, 18(2), 123-143.

Pitt, L., Parent, M., Berthon, P., \& Steyn, P. G. (2010). Event sponsorship and ambush marketing: Lessons from the Beijing Olympics. Business Horizons, 53(3), 281-290. doi: http://dx.doi.org/10.1016/j.bushor.2010.01.002

Portlock, A., \& Rose, S. (2009). Effects of ambush marketing: UK consumer brand recall and attitudes to official sponsors and non-sponsors associated with the FIFA World Cup 2006. International Journal of Sports Marketing and Sponsorship, 10(4), 271-286.

Robinson, T., \& Bauman, L. (2008). Winning the Olympic marketing game: Recall of logos on clothing, equipment and venues at the 2006 Winter Olympics. International Journal of Sports Marketing and Sponsorship, 9(4), 290-305.

Sandler, D.M., \& Shani, D. (1989). Olympic Sponsorship vs. 'Ambush' Marketing: Who Gets the Gold? Journal of Advertising Research, 29(4), 9-14.

Séguin, B., Lyberger, M., O'Reilly, N.J., \& McCarthy, L. (2005). Internationalising ambush marketing: a comparative study. International Journal of Sports Marketing \& Sponsorship, 6(4), 216-230.

Shani, D., \& Sandler, D.M. (1998a). Ambush marketing: Is confusion to blame for the flickering of the flame? Psychology and Marketing, 15(4), 367-383.

Shani, D., \& Sandler, D.M. (1998b). Ambush marketing: is confusion to blame for the flickering of the flame? Psychology \& Marketing, 15(4), 367-383.

Stuart, S.A., \& Scassa, T. (2011). Legal Guarantees for Olympic Legacy. Entertainment \& Sports Law Journal, 9(1), 121.

Taylor, C.R. (2012). The London Olympics 2012: What advertisers should watch. International Journal of Advertising, 31(3), 459-464.

Townley, S., Harrington, D., \& Couchman, N. (1998). The Legal and Practical Prevention of Ambush Marketing in Sports. Psychology \& Marketing, 15(4), 333-348.

Tranfield, D., Denyer, D., \& Smart, P. (2003). Towards a methodology for developing evidence-informed management knowledge by means of systematic review. British Journal of Management, 14, 207-222.

Weed, M. (2005). "Meta Interpretation": A Method for the Interpretive Synthesis of Qualitative Research. Forum Qualitative Social Research, 6(1), Art. 37.

AUTHOR'S ADDRESS:
Monika Piątkowska monika.piatkowska@awf.edu.pl Department of Organisation and History of Sport Josef Pilsudski University of Physical Education in Warsaw Marymoncka 34 00-968 Warsaw Poland 